\title{
Pragmatische partikels in de rechterperiferie
}

\author{
Ton van der Wouden en Ad Foolen*
}

"Verglichen mit dem linken Rand hat der rechte Satzrand bislang
wenig Aufmerksamkeit in der Linguistik erhalten." (Averintseva-Klisch 2009:1)

\section{Inleiding}

In de structuur van de Nederlandse zin neemt de werkwoordelijke eindgroep een prominente plaats in. Koster (1975) bracht dit inzicht pregnant tot uitdrukking door het Nederlands een SOV-taal te noemen. Tegelijk is in de moderne taalkunde ook steeds het besef aanwezig geweest dat het werkwoord niet altijd het laatste woord in de zin heeft, en dat er nog een of meer woordgroepen op kunnen volgen. Om zulke groepen een structurele plaats toe te kunnen wijzen, zijn topologische aanduidingen als 'laatste zinsplaats' en 'uitloop' in het leven geroepen. We zullen de term 'rechterperiferie' gebruiken om deze en eventueel te postuleren andere plaatsen na de werkwoordelijke eindgroep overkoepelend aan te duiden.

In onze bijdrage zullen we ons richten op een specifiek verschijnsel in de rechterperiferie dat met name in gesproken taal te observeren is, namelijk het voorkomen van pragmatische partikels. Daarmee bedoelen we woorden (en soms combinaties van woorden) die niet bijdragen aan de propositionele inhoud van de zin (vgl. Foolen 1993) maar eerder op het niveau van de verhouding tussen spreker en hoorder en in relatie tot andere aspecten van de context fungeren. In analogie met de in het Engels gebezigde aanduiding 'pragmatic marker' hadden we ook voor 'pragmatische markeerder' kunnen kiezen, maar dat klinkt wat omslachtig. Vaak zullen we eenvoudigweg ook van partikel spreken.

Bob Kirsner heeft in samenwerking met co-auteurs tussen 1990 en 2000 aandacht besteed aan zinsfinale partikels als hoor, zeg, hè en joh (zie Kirsner en Deen 1990, Kirsner, Van Heuven en Van Bezooijen 1994, Kirsner en Van Heuven 1996, Kirsner 2000). In deze artikelen werd aandacht besteed aan de interactionele betekenis van deze partikels en daarnaast ook aan de prosodische kenmerken die typisch optreden bij de realisering van deze partikels. Wat in deze publicaties niet aan de orde kwam, is de vraag waar deze elementen syntactisch geplaatst moesten worden. Als laatste zinsplaats en uitloop daarvoor de beschikbare opties zijn, waar staan ze dan: op de laatste zinsplaats, in de uitloop of nog ergens anders?

Tegen de achtergrond van enerzijds de topologische literatuur en anderzijds de studies van Kirsner en zijn co-auteurs, willen we in deze bijdrage een poging doen om het topologische beeld van laatste zinsplaats en uitloop en de observatie dat het Nederlands zinsfinale partikels kent, in relatie tot elkaar te bespreken. Het artikel is als volgt opgebouwd. In par. 2 bekijken we wat een aantal neerlandistische auteurs over de rechterperiferie gezegd heeft. In par. 3 vergelijken we de topologische (en generatieve) analyse van zinsfinale partikels met een meer constructioneel gerichte aanpak. In par. 4 volgt dan een beschrijvend overzicht van een aantal zinfinale partikels in het Nederlands. In par. 5 maken we een korte vergelijking met zinsfinale partikels in andere talen en in par. 6 bekijken we waar pragmatische partikels verder nog in de Nederlandse zin kunnen staan. Par. 7 besteedt aandacht aan een bijzonder verschijnsel, namelijk het tweemaal voorkomen van eenzelfde partikel, in het middenveld en zinsfinaal. In par. 8 zeggen we iets over diachroon onderzoek (grammaticalisering) en par. 9 bevat de conclusie.

\footnotetext{
*Meertens Instituut, ton.van.der.wouden@meertens.knaw.nl en Radboud Universiteit Nijmegen, a.foolen@let.ru.nl. Wij zijn de deelnemers aan de Dag van de Nederlandse Zinsbouw in Gent, de anonieme beoordelaars en de redactie van Nederlandse Taalkunde dankbaar voor hun suggesties en commentaar.
} 


\section{De rechterperiferie in de neerlandistische literatuur}

"Alles wat achter de eindgroep staat heet uitloop", zo stipuleert Paardekooper (1968:47). De uitloop kan volgens hem wel meer dan een zinsdeel bevatten (p. 399): [W]e zijn gaan rijden gisteravond, omdat het mooi weer was. De ANS (Haeseryn et al. 1997:1228-29) onderscheidt structureel twee posities. Direct op de werkwoordelijke eindgroep (tweede pool genoemd) volgt de laatste zinsplaats, die bepaalde zinsdelen of zinsdeelstukken bevat. Daarna volgt nog een positie waarvoor de term uitloop gebruikt wordt, waar "elementen voorkomen die een lossere band met de zin hebben, dat wil zeggen niet op directe wijze een zinsdeelfunctie in de eigenlijke zin vervullen" (p. 1228). De elementen in de uitloop kunnen van verschillende aard zijn (p. 1398-99):

- $\quad$ elementen met een verwijswoord in de eigenlijke zin: Stonden die er al lang, die bomen?

- $\quad$ verduidelijkende toevoeging zonder verwijswoord: Hij is al wel tien keer in Zwitserland geweest, om gezondheidsredenen (namelijk).

- $\quad$ emotioneel geladen exclamatieve toevoegingen: Hij heeft geen dak boven zijn hoofd, de stakker. de tijd.

De afscheiding door komma-intonatie lijkt voor de ANS het gemeenschappelijke kenmerk van deze constructies te zijn op basis waarvan ze allemaal als elementen in de uitloop beschouwd worden.

In het kader van generatieve analyses is de nodige aandacht besteed aan de laatste zinsplaats en de uitloop (bv. Veld 1993, Kluck \& De Vries te verschijnen). Ook voor het Duits bestaat een uitvoerige literatuur over deze posities, vgl. bv. Averintseva-Klisch (2009) over rechtsdislocatie ('NP-Rechtsversetzung') en Schneider-Wiejowski (2010). De discussie heeft zich daarbij vooral gericht op de vraag of de constituenten op deze posities daar via verplaatsing op terecht gekomen zijn of dat ze 'basisgegenereerd' zijn. Daarbij wordt voor extrapositie (laatste zinsplaats) meestal verplaatsing aangenomen, terwijl voor rechtsdislocatie (uitloop) aangenomen wordt dat het om basisgegeneerde constituenten gaat.

Uijlings (1956) is een van de weinige auteurs in de vroegere neerlandistiek die haar analyses op gesproken taal baseert. Haar data kwamen tot stand door proefpersonen afbeeldingen te laten beschrijven. Uijlings stelt vast dat constructies als het is geen jong iemand deze non vaak in haar materiaal voorkomen. In termen van de ANS zou deze non in de uitloop staan, maar het criterium van de komma-intonatie blijkt in de praktijk heel ongewis: "Uit ons materiaal blijkt [...] dat de pauze in het geheel niet aanwezig behoeft te zijn" (Uijlings 1956:49).

Over de plaatsing van pragmatische partikels in relatie tot de laatste zinsplaats en uitloop hebben we in de neerlandistische literatuur weinig kunnen vinden. De Vriendt (1995:157) stelt vast dat zeg normaal een zin afsluit. "Het enige wat er bij kan staan en er dan op volgt is een uitloop of een 'vocatief': Je ziet er vreselijk down uit zeg. Hij zag er heel erg vermoeid uit zeg na de wedstrijd. Je ziet er vreselijk down uit zeg, Jan." Anders dan de ANS, maar net als Paardekooper, gebruikt De Vriendt de aanduiding 'uitloop' voor na de wedstrijd, terwijl hij aan de vocatief Jan geen speciale structurele positie toewijst. Wij zullen in dit artikel voor uitloop de omschrijving volgen zoals de ANS die geeft, zie hierboven. We kunnen zeggen dat in de visie van De Vriendt zeg vooraf gaat aan zowel laatste zinsplaats als uitloop.

Van der Wouden (2009) heeft zinsfinale bijwoorden en hun onderlinge relatie bekeken. Hij observeert dat er na de werkwoordelijke eindgroep behalve de bekende kandidaten als voorzetselgroepen en bijzinnen ook allerlei soorten 'kale' bijwoorden mogelijk zijn: temporele als gisteren, modale als waarschijnlijk, maar ook pragmatische partikels als kortom, bovendien, overigens, trouwens, dan, eigenlijk, integendeel en hoor. Als elementen als 
kortom of bovendien op hun eentje na de werkwoordelijke eindgroep voorkomen, lijkt komma-intonatie mogelijk, maar niet verplicht:
a Het viel ze erg tegen (,) kortom.
b Daar ben ik helemaal niet voor gekleed (,) bovendien.

Het is daarom moeilijk uit te maken of deze partikels de laatste zinsplaats of de uitloop bezetten of ervoor, erna of ertussenin staan. We hebben gezien dat volgens De Vriendt zeg vóór laatste zinsplaats (na de wedstrijd) en uitloop (Jan) staat, terwijl Van der Wouden (p. 151) meent dat hoor heel goed tussen beide posities in kan staan, vgl. (2):

Hij zou zich steeds weer verzetten tegen een dergelijk voorstel hoor, die kerel.

Merk op dat vóór hoor nog het voorzetselvoorwerp tegen een dergelijk voorstel op de laatste zinsplaats staat. Ook plaatsing van hoor tussen werkwoordelijke eindgroep en laatste zinsplaats klinkt acceptabel:

Hij zou zich steeds weer verzetten hoor tegen een dergelijk voorstel.

Maar plaatsing na de uitloop (tegen een dergelijk voorstel, die kerel, hoor) lijkt uitgesloten. Een partikel als integendeel lijkt daarentegen juist een sterke voorkeur te hebben om na een klassieke uitloop te staan (p. 150):

(4) a Hij heeft het je nooit gegeven, dat boek, integendeel.

b ??Hij heeft het je nooit gegeven, integendeel, dat boek.

Pragmatische partikels lijken dus variabel plaatsbaar te zijn: voor de laatste zinsplaats, tussen de laatste zinsplaats en de uitloop, en na de uitloop, waarbij sommige partikels (hoor bv.) zich flexibel gedragen en andere slechts op een van de posities kunnen voorkomen (integendee). Van der Wouden laat in het midden hoe deze observaties theoretisch verantwoord kunnen worden, maar een "proliferatie van syntactische posities" lijkt hem geen aanlokkelijk perspectief (p. 151). In de volgende paragraaf gaan we nader in op een mogelijke theoretische verantwoording van deze positionele observaties.

\section{Generatief, constructioneel of multifactorieel?}

In het bijzonder sinds Cinque (1999) zijn in de generatieve benadering van de zinsstructuur verschillende functionele projecties voorgesteld die zich op het niveau van de discourse bewegen, zoals 'topic' (TopP) en 'focus' (FocP), vgl. Breul (2004). In het verlengde daarvan zijn voor verschillende talen voorstellen gedaan om discoursepartikels die in de linker- of rechterperiferie voorkomen in eigen functionele projecties onder te brengen, zie Poletto (2009) voor het Ouditaliaans, Li (2006), Sybesma en Li (2007) en Sybesma (2010) voor het Chinees, en Haegeman en Hill (2010) voor het Roemeens en het West-Vlaams.

Haegeman en Hill stellen vast dat West-Vlaams wè ('weet') en zè ('zie') eerder een houding van de spreker uitdrukken, terwijl zé (met stijgende intonatie, 'zie') en né ('nietwaar') eerder hoordergericht zijn. Dit verschil in discoursefunctie is voor Haegeman en Hill aanleiding om twee functionele projecties aan te nemen, die twee opeenvolgende partikels uit de twee groepen toelaten, en wel in de volgorde sprekergericht-hoordergericht, bv. wè zé of zè zé. Deze volgorde correspondeert met een dominantieverhouding tussen de twee projecties: de hoordergerichte domineert de sprekergerichte. Zoals de auteurs ook zelf aanduiden, knopen ze hiermee aan bij het idee van Ross (1970) om aspecten van het taalhandelingsniveau in de syntactische structuur in te bouwen. 
Naast spreker- en hoordergerichte partikels zijn er ook elementen die op de samenhang met de voorafgaande discourse gericht zijn, zoals trouwens en eigenlijk, en andere die eerder gericht zijn op wat volgt, als integendeel en het om instemming vragende toch (in tagpositie). In de lijn van Haegeman \& Hill (2010) zou hier aanleiding zijn om voor dit soort discoursegerichte partikels nog andere functionele projecties aan te nemen, waarbij de bepaling van de onderlinge positie van de verschillende projecties in een hiërarchische structuur toenemend lastiger zal zijn. De vraag is, of er een alternatief is.

Wolfgang Imo heeft recentelijk in verschillende publicaties $(2008,2010,2011)$ aandacht besteed aan zinsfinale partikels in het Duits. Hij werkt vanuit een interactioneelconstructioneel kader dat de laatste jaren door Duitse onderzoekers ontwikkeld is (zie bijv. Auer 1991). Met name Imo (2011) is voor onze doeleinden interessant. In een corpus van ongeveer 20 uur getranscribeerde gesprekken trof hij 86 gevallen aan waarin materiaal na de werkwoordelijke eindgroep stond dat niet onder de klassieke gevallen van extrapositie of rechtsdislocatie viel. Opvallend vaak, 51 gevallen, betrof het locale en temporele deictische bijwoorden als hier, da, heute, jetzt. Verder ging het om modale bijwoorden als natürlich, irgendwie, intensiveerders als extrem, absolut, adjectieven als wacker, langsam, modale partikels als halt en einfach, en een restgroep. Imo's centrale vraag was of het hier om performance-verschijnselen gaat, die te interpreteren zijn in termen van incrementele productie waarbij altijd nog iets wat ontbreekt op het eind toegevoegd kan worden, dan wel dat we toch ook deels kunnen spreken van 'constructies', van patronen die regelmatig voorkomen en waaraan we een eigen functie kunnen toekennen. Opvallende regelmatigheden in het corpus waren voor Imo voldoende reden om meerdere constructies aan te nemen. Zo stelt hij voor om de finale deictische bijwoorden niet gelijk te stellen met deictische bijwoorden in het middenveld, maar om er een eigen constructioneel patroon aan toe te kennen met de functie 'Verortung der Äußerung in der Sprechsituation'. Zinsfinale modale partikels als halt bespreekt Imo uitvoeriger in zijn artikel uit 2008. Daar stelt hij voor om voor modale partikels een zekere flexibiliteit in plaatsing toe te staan, samenhangend met nog niet voltooide grammaticalisering. Verdergaande grammaticalisering zal in de toekomst ook een verdere beperking in plaatsing (in dit geval in het middenveld) met zich meebrengen. We zien dat Imo voorstellen doet 'naar bevind van zaken': tegen de achtergrond van de geobserveerde taalgebruiksverschijnselen en met inachtneming van wat we weten over de synchronie en diachronie van het taalsysteem stelt Imo voor om voor zinsfinale partikels ofwel een eigen constructie aan te nemen of om een zinsfinale plaatsing van een partikel onder te brengen bij een constructie die deze plaatsing als een van de mogelijkheden bevat. En ook een duiding als pure reparatie, het op de valreep toevoegen van iets wat beter eerder ingevoegd had kunnen worden, wordt, waar dat plausibel is, zonder meer toegelaten. Met andere woorden: partikels kunnen op verschillende gronden in de rechter periferie terechtkomen. Hoe dan vervolgens de onderlinge volgorde van partikel, laatste zinsplaats en uitloop tot stand komt, is een vraag waarop de constructiegrammatica niet zo makkelijk een antwoord zal hebben. Woordvolgordevariatie is in dat kader nooit een primair aandachtspunt geweest.

Met deze laatste opmerking komt een benadering in beeld die minder de nadruk legt op vooraf, in het taalsysteem vastgelegde, projecties of constructies, maar eerder voorrang geeft aan de visie dat variabele plaatsing vaak mogelijk is en dat de door de spreker gekozen feitelijke plaatsing door meerdere factoren beïnvloed wordt. Deze 'multifactoriële benadering' is in de discussie over woordvolgorde in het middenveld bepleit in Grondelaers (2009) en in de discussie over de linkerperiferie in Evers-Vermeul (2010) opgepakt. Ook Van Bergen (2011) volgt deze aanpak bij haar analyse van variatie bij genitiefbepalingen (Jans auto, Jan z'n auto, de auto van Jan) en bij scrambling in het middenveld. Onze observaties in de rechterperiferie lijken er ook op te wijzen dat er behoorlijk wat variatievrijheid is. Als een spreker een uiting wil produceren waarin verschillende pragmatische partikels gecombineerd worden (al of niet samen met inhoudelijke elementen zoals die op de laatste zinsplaats en uitloop voorkomen) dan zal hij voor een serialiseringstaak waarbij die, zo is ons vermoeden nu, meerdere factoren een rol spelen. Nader kwantitatief onderzoek zal die factoren in kaart moeten brengen; het is te verwachten dat in elk geval één van die factoren 
inhoudelijk-functioneel van aard zal zijn. Zo zal een spreker eerst zijn eigen houding tot uitdrukking brengt alvorens de aandacht via een partikel richting de hoorder te sturen. Evenzo ligt het voor de hand om het terugblikkende trouwens voor het voorwaarts gerichte integendeel te plaatsen (Hij is niet ziek trouwens, integendeel).

Bij deze multifactoriële benadering hoeft niet uitgesloten te worden dat bepaalde partikels vaste posities kiezen die met vaste functies verbonden zijn, zodat er van een constructie gesproken kan worden. En een formalisering van zulke constructies in termen van functionele projecties (als in Haegeman \& Hill 2010) of optimaliteitsconstraints (als in Van Bergen 2011) hoeft daarmee ook niet in tegenspraak te zijn. Een theoretisch gestuurde analyse van partikels in de rechterperiferie heeft echter pas zin als we meer weten van het feitelijke taalgebruik. In de volgende paragraaf zullen we een begin maken met een verkenning van pragmatische partikels in de rechterperiferie.

\section{Een inventarisatie van partikels in de rechterperiferie}

In deze paragraaf bespreken we een aantal voorbeelden van partikels die rechts van de tweede werkwoordelijke pool staan. We hanteren daarbij een indeling naar woordsoorten. Achtereenvolgens komen aan de orde tussenwerpsels, bijwoorden, modale partikels, focuspartikels en voegwoorden. De illustrerende voorbeelden stammen grotendeels uit het Corpus Gesproken Nederlands (CGN).

\subsection{Tussenwerpsels}

Woordjes zoals hoor en hè, joh en zeg, die traditioneel als tussenwerpsels worden gecategoriseerd, zijn vaak op het einde van uitingen te observeren (vgl. de publicaties van Kirsner hierover, o.a. Kirsner \& Van Heuven 1996). Twee van de genoemde elementen, namelijk hoor en zeg, zijn van verbale oorsprong, joh is volgens Van Dale oorspronkelijk nominaal (< jongen, Den Boon et al. s.v.), en van hè is geen etymologie bekend, het WNT (Zesde deel, 1912, 173-175) doet er in elk geval geen uitspraken over. Waarschijnlijk ligt er aan hè geen referentiële betekenis ten grondslag.

De genoemde tussenwerpsels zijn regelmatig in een positie na de tweede werkwoordelijke pool te vinden, vgl. (5):

(5) a ja dan moet je ook zeker wel bijlezen soms hoor.

b is echt ver te zoeken bij hem joh.

c en dan heb je een hele hoop te doen in huis hè.

d maar da 's klote dat je net verkouden wordt dan zeg.

In (5a-c) staan de partikels na de laatste zinsplaats. We hebben eerder al vastgesteld dat plaatsing tussen werkwoord en laatste zinsplaats ook mogelijk is, zie vb. (3). Zo zou in (5d) zeg wel tussen klote en dat kunnen staan. In voorbeeld (6) wordt de laatste zinsplaats door een objectzin bezet en daar lijkt plaatsing helemaal achterop de voorkeur te hebben:

(6) a ik heb nooit gezegd dat de land- en tuinbouw stilstaat hoor/hè/joh/zeg

b ik heb nooit gezegd ?hoor $/$ ?hè $/{ }^{*}$ joh $/{ }^{*}$ zeg dat de land- en tuinbouw stilstaat

Combineren we dit soort partikels daarentegen met onmiskenbare uitlopen, dan lijkt er geen uitgesproken voorkeur in volgorde te bestaan:

(7) a die heb ik ook gekend die kerel, hoor/hè/joh/zeg

b die heb ik ook gekend, hoor/hè/joh/zeg, die kerel

We stellen vast dat er geen strikte volgorde is voor partikels in relatie tot propositioneel materiaal op de laatste zinsplaats en in de uitloop. De serialisering lijkt van verschillende 
factoren af te hangen. Pas met behulp van een groter corpusonderzoek kunnen de relevante factoren en hun invloed op de plaatsing van constituenten en partikels in de rechterperiferie in kaart gebracht worden.

\subsection{Modale partikels}

Woorden als misschien, toevallig en soms kunnen gebruikt worden om vragen beleefder te maken. Dan zijn ze te beschouwen als modale partikels. Het is dan ook niet verbazend dat we ze in het middenveld aantreffen.

(8) a heeft u soms een één of andere stofzuiger in de aanbieding?

b bent u misschien iets kwijt?

c weet je toevallig waar ie die bewaarde?

Met (voor ons gevoel) dezelfde bijdrage aan de interpretatie vinden we ze echter ook wel in zinsfinale positie:

(9) a heeft u vastgezeten in Oostenrijk toevallig?

b heeft iemand het gezien of gehoord soms?

c had u dan de lerarenopleiding Nederlands willen doen misschien?

Het voorbeeld in (9a) laat zien dat toevallig na de laatste zinsplaats staat. De variant (9a') met toevallig in een positie voor de voorzetselgroep is ook wel mogelijk maar klinkt minder goed.

?heeft u vastgezeten toevallig in Oostenrijk?

Door na toevallig een komma in te voegen, wordt de uiting weer beter; in Oostenrijk krijgt dan de status van 'vergeten uitloop'. De geobserveerde flexibele plaatsing van toevallig past bij wat Imo (2008) voor halt heeft geobserveerd. Plaatsing in de rechterperiferie lijkt een interpretatie als modaal partikel niet te belemmeren.

\subsection{Focuspartikels}

In het corpus vinden we de bekende focuspartikels ook, alleen en zelfs regelmatig in posities na de verbale eindgroep:

(10) a jij hebt dus ons ingeschreven voor voorlezen ook.

b ja oké maar ja da's als je mentor bent ook.

c en dan moet je tijgerbalsam kopen ook.

d dan kun je eigenlijk wel ontzettend veel gaan doen zelfs.

e ik heb ook een plank opgehangen zelfs.

$f \quad d$ 'r zit niet echt een verhaal in alleen. da's wel jammer.

$\mathrm{g}$ die is aan 't mopperen alleen.

Voorbeeld (10a) laat zien dat ook na de laatste zinsplaats staat - die is hier immers gevuld met de voorzetselgroep voor voorlezen. Ook woordgroepen met focuspartikelfunctie zoals met name en maar liefst komen in finale posities voor:

(11) a hij gaf een beetje aan hoe dat in Europa ligt met name.

b maar uh ze springen niet zo heel erg hoog dat ze eroverheen kunnen maar ze springen ver met name. en kangoeroes zijn heel sterk hè. 
Net als bij modale partikels blijkt plaatsing van focuspartikels in de rechterperiferie geen interpretatieproblemen op te leveren (vgl. ook Foolen et al. 2009). We nemen aan dat de prosodie aangeeft, welk deel van de zin als focus bedoeld is. constructie:

De combinatie (en) nog ... ook lijkt in aanmerking te komen voor de status van aparte

(12) a dus ik moet waarachtig nog opschieten ook.

b en volgens mij kan hij nog rijden ook.

c en ze kan nog goed leren ook.

d dan tuigen ze dat dier nog af ook.

e en nog met vissmaak ook.

De constructie drukt uit dat de spreker dit niet verwacht had, heeft dus miratieve betekenis, vgl. Kim \& Jahnke (2008) voor gelijksoortige observaties voor het Engelse zinsfinale even. Uitingen van dit type zijn typische vervolguitingen en sluiten vaak een culminerend verhaal(tje) af. Als ook vóór nog in het middenveld geplaatst wordt (en ze kan ook nog goed leren), dan verdwijnt het bijzondere effect, dan wordt het een uiting met 'gewone' additieve betekenis. We zien dit als aanwijzing dat er bij (en) nog ... ook inderdaad 'constructionalisering' heeft plaatsgevonden.

\subsection{Bijwoorden}

We bespreken slechts een selectie van de bijwoorden die allemaal in de rechterperiferie kunnen voorkomen, we beperken ons voornamelijk tot de voegwoordelijke bijwoorden. Finaal dan komt in het CGN regelmatig voor, zowel bij mededelende zinnen (13) als bij vragen (14): ${ }^{1}$

(13) a ik dacht anders is 't misschien leuk dat wij koken voor uh jouw familie maar Mabel staat op uh die is dan uitgerekend dus die gaat denk ik niet in Bilthoven uit eten dan.

b maar goed uhm ja dus dat is geregeld dan.

(14) a heb jij wel een kattenbak? waar heb je die staan dan?

b 'k zeg want d'r zijn d'r zijn zo veel vacatures. en hoe komt 't dat jij niet aan de bak komt? heb je daar al eens bij stilgestaan dan?

In een enkel geval vonden we materiaal tussen de tweede pool en dan: ${ }^{2}$

a welk bos heb jij gewandeld gister dan?

b we zijn best wel bang voor hoe 't volgend jaar gaat worden in de winkel dan.

De betekenis van dan varieert. In vragen motiveert dan de vraag, is dan dus eerder een modaal partikel, terwijl in mededelende zinnen een parafrase met 'in dat geval' mogelijk is, wat duidt op een referentiële impact.

Immers en namelijk komen ook finaal voor, maar niet zo vaak.

\footnotetext{
${ }^{1}$ Voor bespreking van cognaten van dan in dialecten zie oa. Haegeman (1991) en Capelle (1993). Finaal dan geldt ook als een kenmerk of sjibboleth voor verschillende Hollandse stadsdialecten: kejje nie hore dattik uit Roterdam komp dan? Komie uit Leie dan? maar over de functie ervan in het taalgebruik is weinig te vinden: het blijft niet ongenoemd in de werken van Heestermans (2007), Jansen (1981) en Wortel (2002), maar we zochten vergeefs naar een analyse. Zie ook voetnoot 24 in Van der Wouden (2009).

${ }^{2}$ Niet zeldzaam in finale positie is dan ook, zoals in ja maar er zijn geen aanslagen of zo of wat dan ook, maar de combinatie fungeert dan doorgaans als een apart lexicaal element dat onbepaalde voornaamwoorden markeert, cf. Paardekooper (1978).
} 
(16) a ja. maar ja je moet ook iedere keer op de grond zitten immers.

b want uh ik heb 't ook op mijn andere computer immers.

(17) a het smaakt alsof het losse thee is namelijk.

b ja maar ik weet niet of dat hierin staat namelijk.

Het voegwoordelijk bijwoord dus komt ook regelmatig finaal voor, maar komt ook op andere plekken voor. We beperken ons hier tot een aantal voorbeelden en verwijzen verder naar de functionele analyse van Degand in haar bijdrage aan dit discussienummer over de rechterperiferie.

(18) a die avond moest 't gebeuren dus.

b ik werd om half negen wakker gebeld dus.

c die heeft 't nog nooit zo druk gehad als nu dus.

d ik heb er nooit moeite mee gehad hoor dus.

Voorbeeld (18c) laat zien dat dus na de laatste zinsplaats kan staan; in (18d) staat het na hoor.

We hebben in het CGN ook gezocht naar finaal hoewel, maar dat is erg zeldzaam. Niettemin is het reflecterende hoewel op het einde van de zin heel herkenbaar voor native speakers als je hun voorbeelden voorlegt, vgl.: De ene revolutie is de andere niet ..... hoewel?

\subsection{Voegwoorden}

McGloin \& Konishi (2010) observeren dat in het Japans het voegwoordelijk partikel shi 'en' zinsfinaal gebruikt kan worden. In bepaalde varianten van het Engels is het voegwoord but zinsfinaal geobserveerd, zie Mulder et al. (2009) en Hancil (2010). Het CGN biedt volop gevallen van finaal en, maar en of:

(19) a ik weet weet niet hoe dat precies komt maar dan gaan ze hier al kabaal maken en...

b ja ze is gewoon zeiknat en...

c ja daar heb ik alleen niet zo heel veel foto's van maar...

d die staat hier nog niet op maar...

e wat is dit voor foto is die niet afgedrukt of...

$f \quad$ dan ga 'k er vaak net iets te slap in of ik mis de bal gewoon of...

In het algemeen kun je in het Nederlands echter niet zomaar een zin afsluiten met een voegwoord:
a $\quad{ }^{*} \mathrm{Hij}$ is lief maar.
b *Hij verkoopt aardappelen en.
c $\quad$ *Ze wordt later president van de Nederlandse Bank of.

Deze zinnen, of beter uitingen, zijn echter wel goed als we een aarzelingsmarkeerder als $u h$ toevoegen:

(20) a' Hij is lief maar uh

b' Hij verkoopt aardappelen en uh

c' Ze wordt later president van de Nederlandse Bank of uh

\footnotetext{
${ }^{3}$ http://www.artikel7.nu/?p=48080 (geraadpleegd 29 april 2011).
} 
Het corpus bevat inderdaad heel veel gevallen van uitingen die afgesloten worden met een voegwoord gevolgd door een expliciet getranscribeerde aarzeling:

(21) a die kan ook zichzelf even voorstellen en uh...

b maak je een plattegrondje en dan kan je d'r banken neerzetten en uh...

c ' 'k heb 'm natuurlijk niet zo lang gekend maar uh...

d nou da*a d'r is op zich wel wat voor te zeggen maar uh...

e komt dat omdat die ouders zoveel geld hebben of uh...

f we kunnen 't boodschappenlijstje met $u$ doornemen of uh...

We hebben de indruk dat de drie aarzelingspuntjes zonder uh in de voorbeelden in (19) eveneens verwijzen naar een aarzelingsgeluid, dat in de orthografische transcriptie van het corpus niet verder 'uitgespeld' is.

Nader onderzoek zal moeten uitwijzen of combinaties als en uh en of uh opgevat kunnen worden als elementen met een primair gespreksorganiserende functie ("ik geef als spreker aan dat ik de beurt zou kunnen voortzetten, maar dat de hoorder ook mag overnemen"). Mocht het antwoord op deze onderzoeksvraag positief zijn, dan is een vervolgvraag of deze elementen kunnen worden opgevat als de meest algemene gevallen van "general extenders" in de zin van Overstreet (1999) (cf. ook Van der Wouden 2011).

Dit overzicht laat in ieder geval één ding zien: het mondelinge Nederlands bevat velerlei vormen van pragmatische afronding van een uiting. Dat het Nederlands daarin niet uniek is, willen we kort illustreren met de volgende paragraaf.

\section{Zinsfinale partikels in andere talen}

Als we de Nederlandse zinsfinale partikels in een taalvergelijkend perspectief willen bekijken, ligt het voor de hand om binnen de Germaanse taalfamilie te beginnen. Het Noors lijkt meer gebruik te maken van zinsfinale partikels dan de andere Germaanse talen, tenminste als we afgaan op het aantal publicaties dat eraan gewijd is, zie Andvik (1992), Askedal (1989) en Fretheim (1989, 1991, 2010). Askedal (1989) probeert het typologische verschil tussen het Duits, met zijn modale partikels in het middenveld, en het Noors, met de vele zinsfinale partikels, vanuit een typologische benadering te verklaren. Noors zou SVO zijn en het Duits SOV. Serialisering vindt vanuit V plaats: eerst de nauw daarbij aansluitende $\mathrm{O}$, vervolgens de lossere partikels. Die komen dan in het Duits links van $\mathrm{O}$ terecht, resulterend in een middenveldpositie en in het Noors rechts van O, zinsfinaal. De voorspelling zou dan zijn dat het Nederlands (SOV) op dit punt typologisch met het Duits meegaat en het Engels (SVO) met het Noors. Voor het Nederlands klopt dit wel. Het Engels kent weinig partikels, dus daar is de voorspelling moeilijk te testen. Daarom is het zinvol om de blik te verruimen en ook naar andere taalfamilies te kijken.

Buiten Europa zijn het met name de Oost-Aziatische talen waarvoor zinsfinale partikels onderzocht zijn. Gerapporteerd wordt, dat ze in deze talen net als in het Noors heel prominent aanwezig zijn, vgl. voor het Japans o.a. Lee (2007), Haugh (2008), McGloin \& Konishi (2010) en Hayano (2011), en voor (verschillende varianten van) het Chinees Li (2006), Lin (2010), Sybesma \& Boya (2007), Sybesma (2010), Strauss \& Xiang (2009), Lee \& Pan (2010). Typologische verschillen lijken daarbij een ondergeschikte rol te spelen. Het Japans is SOV en het Chinees SVO maar de talen lijken niet te verschillen in het veelvuldige gebruik van zinsfinale partikels in de gesproken taal. Er lijkt dus aanleiding om vraagtekens te plaatsen bij Askedals typologische verklaring voor partikelplaatsing.

Als alternatief verkennen we hier een pragmatische invalshoek. Het is denkbaar dat dat er zich rondom de propositionele inhoud een aantal 'natuurlijke' posities bevinden waar partikels (en ander "toegevoegd" materiaal, cf. bijv. Schelfhout 2006) zich thuis voelen: Het begin en het einde van de uiting, en wellicht ook de positie tussen thema en rhema, de informationele 'luwte' in het middenveld, vgl. Krivonosov (1977), die claimt dat de Duitse 
modale partikels typisch op de waterscheiding van thema en rhema staan. In een bepaalde schrijfstijl kan een partikel ook na een eerste constituent staan (de zgn. Wackernagelpositie), als in Erik nu was een zoon van Karel. Ook hier lijkt informatiestructuur een rol te spelen: Erik krijgt, mede door het partikel, de status van nieuw topic (Van der Wouden 2006).

Tegen deze pragmatische achtergrond zal nader typologisch onderzoek moeten uitwijzen of ook de basiswoordvolgorde van een taal een factor is die bijdraagt tot de taalspecifieke voorkeuren voor de plaatsing van pragmatische partikels.

\section{Partikels in verschillende posities in het Nederlands}

In paragraaf 5 hebben we de mogelijke posities voor pragmatische partikels geïnventariseerd. Als we nu naar het Nederlands kijken dan zien we dat (behalve de werkwoordelijke polen) alle posities inderdaad gebruikt worden.

(22) Aanloop:

nou ik zie dat plan met de vakantie ook echt niet zitten hoor.

(23) Eerste positie:

nou heb ik 't weer gedaan.

(24) Wackernagelpositie

In den beginne schiep God de hemel en de aarde. De aarde nu was woest en ledig, en duisternis lag op de vloed, en de Geest Gods zweefde over de wateren. (Genesis 1: 1-2, Willibrordvertaling)

Middenveld

dat was nou echt een paradepaardje voor ons.

Rechterperiferie

ik kan je ook wel aanraden de reader te lezen trouwens hoor.

Rechterperiferie

ik kan je ook wel aanraden de reader te lezen trouwens hoor.

Sommige partikels hebben een beperkte distributie: de meeste modale partikels komen alleen voor in het middenveld, en hoor is beperkt tot een positie aan het eind van de zin. Andere partikels komen op verschillende posities in de zin voor, zoals kortom (28):
a kortom 't is gewoon een hele belabberde situatie.
b je kijkt er kortom niet met veel vreugde op terug.
c pleit ervoor dat ze wel mogen gehoord worden de pleegouders kortom.

(28c) klinkt in onze oren niet zo goed, maar is wel aangetroffen. Een vergelijkbaar rijtje voorbeelden kunnen we voor trouwens geven.

$$
\begin{aligned}
& \text { a trouwens jij moest mij nog iets vertellen over die husky of niet? } \\
& \text { b dat had ik trouwens in 't vorige gesprek ook al gezegd volgens mij. } \\
& \text { c ja we hebben ook wel heel veel ruzie gemaakt hoor trouwens. }
\end{aligned}
$$

Het laatste voorbeeld is interessant omdat hoor hier voor trouwens staat. De functie van de drie voorbeelden in de discourse is verschillend: in het eerste voorbeeld wordt een topic ge(her)introduceerd, het tweede voorbeeld is meer een terechtwijzing, terwijl in (29c) de spreker iets toegeeft. In alle voorbeelden indiceert de spreker met trouwens dat hij beseft dat de aansluiting met het voorgaande een breuk vertoont. Die functie lijkt stabiel, onafhankelijk van de plaatsing in het middenveld of in de linker- of rechterperiferie. Eenzelfde rijtje is te maken met bovendien:

(30) a bovendien was ik het enige meisje en de jongste in het gezin.

b marihuana is bovendien niet of nauwelijks verslavend. 
c daar ben ik helemaal niet voor gekleed bovendien.

In het eerste voorbeeld kan bovendien ook in de linkerperiferie staan. Bij verplaatsing naar de rechterperiferie zou het uitmaken of het einde van het eerste of tweed conjunct gekozen wordt. Bij plaatsing na het tweede conjunct heeft bovendien alleen betrekking op dat tweede conjunct.

Aan de reeks kortom, trouwens en bovendien kan nog overigens toegevoegd worden. Het gaat hier om gespreksstructureerders. Die functie is blijkbaar zo duidelijk met deze woorden verbonden, dat ze die behouden, waar ze ook staan. Bij sommige partikels is er met enige goede wil een licht betekenisverschil te signaleren, vgl. (31):

(31) a Dat is toch vreselijk?

b Dat is vreselijk toch?

Het komt ons voor dat de tweede variant wat sterker op de hoorder georiënteerd is, in die zin dat er wat sterker een beroep gedaan wordt op de hoorder om toch alsjeblieft met een (instemmende) reactie te komen, terwijl in het eerste geval de expressieve kracht, dus de sprekersoriëntatie, sterker lijkt te zijn. Maar het verschil is eerder gradueel dan absoluut. Verder onderzoek naar de relatie tussen plaatsing en betekenis(verschuiving) is ook hier weer nodig (vgl. de bijdrage van Degand in dit nummer en ons commentaar daarbij).

\section{Verdubbeling}

Een verschijnsel dat we vooraf niet verwacht hadden maar dat we te vaak aantroffen om te kunnen negeren, is het voorkomen van een en hetzelfde partikel zowel vooraan of midden in de zin als in de rechterperiferie. In (32) staan een paar corpusvoorbeelden met dan:

(32) a dan hebben die vissen wel veel te veel gegeten dan.

b nou hij heeft mijn nek dan ook gekraakt dan.

c dan heb je slechte bloedvaten dan.

d ik denk ja laat ik dan maar die kleine halen dan.

Dan is een partikel dat relatief vaak dubbel voorkomt. Het is opmerkelijk dat ook in het Noors da 'dan' makkelijk tweemaal voor blijkt te kunnen komen, vgl. Fretheim (1991:184):

(33) De sov da hjemme, da wel?

Zij sliepen dan thuis, dan wel?

'Ze hebben toch wel thuis geslapen, hè?'

Ook Askedal (1989:695) geeft voorbeelden van verdubbelingen van da:

(34) Det var da fælt så lenge han ble da

'Dat blijft dan heel lang dan'

Een verklaring voor dit fenomeen zou kunnen zijn dat de pragmatische functie van dan inderdaad naar twee kanten werkt. Enerzijds geeft de spreker met dan aan dat zijn opmerking door het voorgaande gemotiveerd is, anderzijds legt hij zijn uiting aan de hoorder voor ter becommentariëring, of beter ratificering.

Behalve dan komt ook toch verdubbeld voor:

(35) ja dat zijn toch dingen die heel makkelijk te veranderen zijn op zich toch. 
We hebben al eerder gezegd dat toch in het middenveld iets meer spreker-expressief is en in de uitloop meer hoordergericht. Uitingen als dat is toch verschrikkelijk, toch? klinken niet vreemd. Als derde verdubbelbaar partikel hebben we ook aangetroffen.

(36) a och ja da's ook waar ook.

b kun je ook nog nalezen ook.

c dan zijn we er op een gegeven moment ook van af ook. en die kunnen nog lekker eten ook nog.

In (36) b en c vindt de verdubbeling plaats in het kader van de constructie die we eerder als de nog ...ook-constructie aangemerkt hebben. De eerste positie kan blijkbaar met ook versterkt worden en de tweede met nog:

het regent nog behoorlijk ook nog.

Zoals eerder gezegd, de constructie druk verbazing uit, is dus expressief. Dat zou in dit geval een verklaring kunnen zijn voor de verdubbelingsverschijnselen, zowel bij de eerste als de tweede pool van de constructie.

\section{Grammaticalisering van zinsfinale partikels}

Pragmatische partikels zijn typisch het resultaat van grammaticaliseringsprocessen. Inhoudswoorden, maar ook al bestaande functiewoorden, ontwikkelen een sterk interactioneel en discourse-potentieel en die ontwikkeling gaat gepaard met voorkeuren voor posities die voor pragmatische functies 'natuurlijk' lijken, waaronder de rechterperiferie. Het onderzoek op dit gebied kent nog de nodige terminologische onzekerheden, waarbij o.a. de verhouding tussen grammaticalisering, pragmaticalisering en subjectificatie in het geding is, vgl. Degand \& Simon-Vandenbergen (2011).

Voor het Nederlands moet het onderzoek naar de diachrone ontwikkeling van zinsfinale partikels nog grotendeels op gang komen, maar zie Evers-Vermeul et al. (2011) als een methodisch goed voorbeeld van hoe zulk onderzoek eruit kan zien. Voor het Engels is al wel het een en ander gedaan, zie Barth en Couper-Kuhlen (2002) over though, Lewis (2011) over rather en Zwicky (2008), Mulder, Thompson en Williams (2009) en Hancil (2010) over but.

Bij though en but lijkt een type grammaticaliseringsproces gespeeld te hebben dat ook voor andere talen geobserveerd is, vgl. Lin (2010) voor la in het Mandarijn van Taiwan. Volgens Lin wordt la normalerwijze gevolgd door een 'elaboration', maar als dat vervolg weggelaten wordt, dan ontstaat de implicatie "this is what I want to say and you should know" (Lin 2010:111). lets soortgelijks lijkt bij Engels finaal though aan de hand te zijn. Barth-Weingarten en Couper-Kuhlen (2002:348) bespreken het voorbeeld it's their right to be heard though en geven als commentaar: "Final though here concedes a prior point but it does not make this point explicit. It is loosely anaphoric to the $\mathrm{X}$ of prior discourse. Often it seems to be paraphrasable as 'though what you just said is true'." Ook het Nederlandse zinsfinale hoewel lijkt een kandidaat voor dit type grammaticaliseringsproces maar staat waarschijnlijk nog aan het begin daarvan.

Voor andere zinsfinale partikels hebben andere processen een rol gespeeld, bv. via repair-achtige performance-verschijnselen: een vergeten partikel wordt 'alsnog' gerealiseerd en als dit vaker gebeurt wordt allengs de finale realisering passabel, waarbij al of niet een eigen functie kan ontstaan. Of de spreker is vergeten dat het partikel al een keer gerealiseerd is, waardoor de in par. 7 besproken verdubbeling ontstaat.

\section{Conclusie}


In mondeling informeel taalgebruik wordt een uiting heel vaak niet eenvoudigweg afgesloten als de propositionele inhoud meegedeeld is. Vaak is er nog een pragmatische afronding in de vorm van pragmatische markeerders. Terwijl die in het Japans en Chinees zinsfinaal lijken te moeten staan, is er voor het Nederlands wat speelruimte in de rechterperiferie. De positionele vrijheden en beperkingen daarbinnen en de factoren die de plaatsing beïnvloeden zullen in toekomstig onderzoek op basis van grootschaliger kwantitatief onderzoek systematischer in kaart gebracht moeten worden.

We hebben in par. 4 al wel terloops aangeduid wat zoal de functies zijn die pragmatische partikels in de rechterperiferie vervullen. Ook op dit punt zal verder onderzoek meer systematiek moeten opleveren. We vatten nog even enkele functies samen die ons zijn opgevallen. Ten eerste: het finale partikel fungeert als tweede deel van een constructie. Net zoals de werkwoordsgroep twee polen heeft, kan een constructie met pragmatische functie die ook hebben. We zijn in ons onderzoek een duidelijk voorbeeld daarvan tegengekomen, namelijk de nog .. ook-constructie, waarbij het ook-deel na de werkwoordelijke tweede pool staat. Vervolgens: De uiting wordt met een afsluitend partikel functioneel gelabeled. De spreker wil bv. aangeven dat hij de hoorder waarschuwend of geruststellend iets op het hart wil drukken (hoor). Of hij wil aangeven dat het voorgaande bedoeld was als een samenvatting of verklaring (kortom, namelijk), of als een uiting waarop de spreker graag de instemmende reactie van de hoorder wil (hè, nietwaar). Ook kan het zijn dat het zinsfinale partikel 'zelfreflecterend' opgeroepen wordt. De spreker inspecteert wat hij heeft gezegd en ziet aanleiding voor nuancering. Partikels en uitdrukkingen als of zo, hoewel, denk ik, $X$ toch (Vlaams toch), althans $X$, relativeren de sterkte van de uiting. De spreker dekt zich daarmee in door (al of niet oprecht) omzichtigheid te tonen. De finale partikels kunnen ook op de beurtwisseling betrekking hebben. We hebben dat gezien bij de finale voegwoorden, in het Nederlands kennelijk verplicht gevolgd door een of ander aarzelingssignaal, waarmee een 'fading out'-effect bereikt wordt. Daarmee wordt de beurtwisseling opengesteld voor onderhandeling, de hoorder kan overnemen of niet. De spreker geeft met zijn open einde aan dat hij eventueel bereid is om door te gaan als de hoorder niet kan of wil overnemen. Dit gedrag ligt in de sfeer van beleefdheid of onzekerheid. Ten slotte kunnen we niet uitsluiten dat het soms gewoon om een 'repair' gaat, een vergeten modaal partikel of focuspartikel. Ik ben toen naar huis gegaan maar is een verzonnen voorbeeld, het kan als 'zoekmodel' voor verder onderzoek fungeren. Zulke 'on line' spreektaalverschijnselen kunnen bij herhaling leiden tot constructies die deel gaan uitmaken van het patroonrepertoire waarop we bij het spreken een beroep kunnen doen.

\section{Bibliografie}

Andvik, Erik E. (1992). A pragmatic analysis of Norwegian modal particles. Dallas, TX: International Academic Bookstore.

Askedal, John Ole (1989). Sprachtypologische Aspekte norwegischer Partikelstrukturen. In: H. Weydt (red.), Sprechen mit Partikeln. Berlin: Mouton de Gruyter, 691-702.

Auer, Peter (1991). Vom Ende deutscher Sätze. Zeitschrift für germanistische Linguistik 19, 139-157.

Averintseva-Klisch, Maria (2009). Rechte Satzperipherie im Diskurs. Die NPRechtsversetzung im Deutschen. Tübingen: Stauffenburg Verlag.

Bart-Weingarten, Dagmar \& Elizabeth Couper-Kuhlen (2002). On the development of final though. A case of grammaticalization. In: Ilse Wischer \& Gabriele Diewald (red.), New reflections on grammaticalization. Amsterdam: Benjamins, 345-361.

Bergen, Geertje van (2011). Who's first and what's next. Animacy and word order variation in Dutch language production. Proefschrift Radboud Universiteit Nijmegen. 
Boon, Ton den, Dirk Geeraerts en Nicoline van der Sijs (2005). Van Dale Groot woordenboek der Nederlandse taal 14e, herz. uitg.Utrecht/Antwerpen Van Dale Lexicografie.

Breul, Carsten (2004). Focus structure in generative grammar. An integrated syntactic, semantic and intonational approach. Amsterdam: Benjamins.

Capelle, Bert (1993). Het gebruik van het Brugse dialoogpartikel dè (/dæ/). neerlandistiek.nl 03.01.

Cinque, Guglielmo (1999). Adverbs and functional heads: A cross-linguistic perspective. New York \& Oxford: Oxford University Press

Degand, Liesbeth \& Anne-Marie Simon-Vandenbergen (2011). Introduction:

Grammaticalization and (inter)subjectification of discourse markers. Linguistics 49:2, 287-294.

De Vriendt, Sera (1995). Kom, kijk, zeg als interjectie. In: Sera De Vriendt, Van geen kleintje vervaard. Essays over Nederlandse taalwetenschap. Brussel: VUB Press, 151-159.

Evers-Vermeul, Jacqueline (2010). Dus vooraan of in het midden? Over vormfunctierelaties in het gebruik van connectieven. Nederlandse Taalkunde 15:2, 149 175.

Evers-Vermeul, Jacqueline, Liesbeth Degand, Benjamin Fagard \& Liesbeth Mortier (2011). Historical and comparative perspectives on subjectification: A corpus-based analysis of Dutch and French causal connectives. Linguistics 49:2, 445-478.

Foolen, Ad (1993). De betekenis van partikels. Een dokumentatie van de stand van het onderzoek met bijzondere aandacht voor maar. Proefschrift Nijmegen.

Foolen, Ad, Richard van Gerrevink, Lotte Hogeweg en Peia Prawiro-Atmodjo (2009). The placement of focus particles in Dutch. In B. Botma en J. van Kampen (red.), Linguistics in the Netherlands 2009. Amsterdam: Benjamins, 51-63.

Fretheim, Thorstein (1989). The two faces of the Norwegian inference particle da. In: H. Weydt (red..), Sprechen mit Partikeln. Berlin: Walter de Gruyter, 403-415.

Fretheim, Thorstein (1991). Formal and functional differences between S-internal and S-external modal particles in Norwegian. Multilingua 10(1/2), 175-200.

Fretheim, Thorstein (2010). The metarepresentational use of main clause phenomena in embedded clauses. Linguistics 48:2, 301-324.

Grondelaers, Stef (2009). Woordvolgorde in presentatieve zinnen en de theoretische basis van multifactoriële grammatica. Nederlandse Taalkunde 14, 282 299.

Haeseryn, Walter, Kirsten Romijn, Guido Geerts, Jaap de Rooij en Maarten C. van den Toorn (1997). Algemene Nederlandse Spraakkunst. 2e, geheel herz. dr. Groningen en Deurne, Martinus Nijhoff en Wolters Plantijn.

Haegeman, Liliane (1993). The interpretation of the particle da in West Flemish. Lingua 90, 111-128.

Haegeman, Liliane (1991/2008). Parenthetical adverbials: The radical orphanage approach. In: Benjamin Shaer et al. (red.), Dislocated elements in discourse. Syntactic, semantic, and pragmatic perspectives. London: Routledge, 580-611. Haegeman, Liliane \& Virginia Hill (2010). The syntactization of discourse. Manuscript.

Hancil, Sylvie (2010). Grammaticalization of sentence-final but: from discourse connective to discourse marker. Lezing International conference on final particles, Rouen, mei 2010.

Haugh, Michael (2008). Utterance-final conjunctive particles and implicatures in Japanese conversation. Pragmatics 18:3, 425-451.

Hayano, Kaoru (2011). Claiming epistemic primacy: Yo-marked assessments in Japanese. In: T. Stivers, L. Mondada, \& J. Steensig (red.), The morality of knowledge in conversation. Cambridge: Cambridge University Press, 58-81.

Heestermans, Hans (2007). Het Leids woordenboek. Leiden: Selexyz Kooyker. 
Imo, Wolfgang (2008). Individuelle Konstrukte oder Vorboten einer neuen Konstruktion? Stellungsvarianten der Modalpartikel halt im Vor- und Nachfeld. In: Anatol Stefanowitsch \& Kerstin Fischer (red.), Konstruktionsgrammatik II. Von der Konstruktion zur Grammatik. Tübingen: Stauffenburg Verlag, 135-155.

Imo, Wolfgang (2010). Das Adverb jetzt zwischen Zeit- und Gesprächsdeixis. Zeitschrift für germanistische Linguistik 38, 25-58.

Imo, Wolfgang (2011). Ad-hoc-Produktion oder Konstruktion? Verfestigungstendenzen bei Inkrement-Strukturen im gesprochenen Deutsch. In: A. Lasch \& A. Ziem (red.), Konstruktionsgrammatik III. Aktuelle Fragen und Lösungsansätze. Tübingen: Stauffenburg Verlag, 239-254.

Jansen, Frank (1981). Syntaktische konstrukties in gesproken taal. Proefschrift Leiden.

Kim, Min-Joo \& Nathan Jahnke (2011). The meaning of utterance-final Even. Journal of English Linguistics 39, 36-64.

Kirsner, Robert S. (2000). Empirical pragmatics: Downtoning and predictability in a Dutch final particle. In T.F. Shannon \& J.P. Snapper (red.), The Berkeley Conference on Dutch Linguistics 1997. (= Publications of the American Association for Netherlandic Studies 12). Lanham, MD: University Press of America, 45-62.

Kirsner, Robert S. \& Jeanine Y. Deen (1990). Het mes snijdt aan twee kanten. On the semantics and pragmatics of the Dutch sentence-final particle hoor. In: M. Bruijn Lucy (red.), The Low Countries: Multidisciplinary studies. Lanham, MD: University Press of America, 1-11.

Kirsner, Robert S., Vincent J. van Heuven en Renée van Bezooijen (1994). Interaction of particle and prosody in the interpretation of factual Dutch sentences. In: R. Bok-Bennema \& C. Cremers (red.), Linguistics in the Netherlands 1994. Amsterdam: Benjamins, 107-118.

Kirsner, Robert S. \& Vincent J. van Heuven (1996). Boundary tones and the semantics of the Dutch final particles hè, hoor, zeg, and joh. In: C. Cremers \& M. den Dikken (red.), Linguistics in the Netherlands 1996. Amsterdam: Benjamins, 133-146.

Kluck, Marlies \& Mark de Vries (te versch.). Cumulative rightward processes. In: H. Walker, M. Sailer \& G. Webelhuth (red.), Rightward movement from a crosslinguistic perspective. Amsterdam: Benjamins.

Koster, Jan (1975). Dutch as an SOV language. Linguistic Analysis 1, 111-116. Krivonosov, Aleksej T. (1977). Deutsche Modalpartikeln im System der unflektierten Worklassen. In: H. Weydt (red.), Aspekte der Modalpartikeln. Tübingen: Niemeyer, 176-216.

Lee, Duck-Young (2007). Involvement and the Japanese interactive particles ne and and yo. Journal of Pragmatics 39, 363-388.

Lee, Peppina Po-Lun \& Hai-Hua Pan (2010). The landscape of additive particles with special reference to the Cantonese sentence-final particle tim. Lingua 120, 1777-1804.

Lewis, Diana (2011). A discourse-constructional approach to the emergence of discourse markers in English. Linguistics 49:2, 415-443.

$\mathrm{Li}$, Boya (2006). Chinese final particles and the syntax of the periphery. Proefschrift Leiden.

Lin, Chin-hui (2010). The utterance-final particle la in Taiwan Mandarin. In: J. van Kampen \& R. Nouwen (red.), Linguistics in the Netherlands 2010. Amsterdam: Benjamins, 101-114.

McGloin, Naomi H. \& Yumiko Konishi (2010). From connective particle to sentence-final particle: a usage-based analysis of shi 'and' in Japanese. Language Sciences 32(5), 507-588.

Mulder, Jean G., Sandra Thompson and C. Perry Williams (2009). Final but in Australian English conversation. In: P. Peters et al. (red.), Comparative studies in Australian and New Zealand English: Grammar and beyond. Amsterdam: Benjamins, 339-359. 
Overstreet, Maryann (1999). Whales, candlelight, and stuff like that: general extenders in English discourse. New York: Oxford University Press.

Paardekooper, Piet C. (1968). Beknopte ABN-syntaksis. Den Bosch: Malmberg. Paardekooper, Piet C. (1978). Wie dan ook enz., vooral als patroondeel. De Nieuwe Taalgids 71, 569-581.

Poletto, Cecilia (2009). Two instances of a broken cycle: Sentential particles in Old Italian. In: E. van Gelderen (red.), Cyclical change. Amsterdam: Benjamins, 185-208. Ross, John Robert (1970). On declarative sentences. In: R.A. Jacobs \& P.S.

Rosenbaum (red.), Readings in English transformational grammar. New York: Oxford University Press, 222-272.

Schelfhout, Carla (2006). Intercalations in Dutch. Proefschrift Radboud Universiteit Nijmegen.

Schneider-Wiejowksi, Karina (2010). Komplexe syntaktische Konstruktionen nach der rechten Satzklammer: Eine Korpusstudie. Muttersprache 2010/1, 57-69.

Strauss, Susan \& Xuehua Xiang (2009). Discourse particles: Where cognition and interaction intersect. The case of final particle ey in Shishan dialect (Hainan Island, P.R. China). Journal of Pragmatics 41, 1287-1312.

Sybesma, Rint (2010). Het loze van tijdenloosheid. Oratie Leiden.

Sybesma, Rint \& Boya Li (2007). The dissection and structural mapping of Cantonese sentence final particles. Lingua 117, 1739-1783.

Uijlings, Bertha J. (1956). Praat op heterdaad. Assen: Van Gorcum.

Veld, Joop (1993). Postverbal constituents in Dutch and Turkish. Proefschrift Amsterdam (= Amsterdam Studies in Generative Grammar 6).

Vries, Matthias de \& Lammert te Winkel e.a. (red.) (1864-1998). Woordenboek der Nederlandsche Taal. 's-Gravenhage [etc.]: Martinus Nijhoff [etc.].

Wortel, Dick (2002). Leids. Den Haag: Sdu Uitgevers.

Wouden, Ton van der (2000). Focus on appendices in Dutch. In: H. de Hoop \& T. van der Wouden (red.), Linguistics in the Netherlands 2000.

Amsterdam/Philadelphia: Benjamins, 233-245.

Wouden, Ton van der (2006). Partikels: woordjes die het Nederlands markeren. In: Nicoline van der Sijs, Jan Stroop, \& Fred Weerman (eds.), Wat iedereen van het NEDERLANDS moet weten en waarom. Amsterdam: Bert Bakker, 119-129.

Wouden, Ton van der (2009). Ik zou weleens willen weten waar dat woord staat trouwens. Aantekeningen over zinsfinale bijwoorden. In: R. Boogaart, J. Lalleman, M. Mooijaart \& M. van der Wal (red.), Woorden wisselen. Voor Ariane van Santen bij haar afscheid van de Leidse universiteit. Leiden: SNL, 143-156.

Wouden, Ton van der (2011). General extenders en zo. Lezing Tindag, 5 februari 2011.

Zwicky, Arnold (2008). Final conjunctions.

http://languagelog.Idc.upenn.edu/nll/?p=119. (geraadpleegd op 22 september 2011). 